\title{
Long-distance transport of hair lambs: effect of location in pot-belly trailers on thermo-physiology, welfare and meat quality
}

\author{
G. C. Miranda-de la Lama ${ }^{1} \cdot$ M. Rodríguez-Palomares ${ }^{2}$ - R. G. Cruz-Monterrosa ${ }^{1}$ • \\ A. A. Rayas-Amor ${ }^{1}$ - R. S. B. Pinheiro ${ }^{3}$ - F. M. Galindo ${ }^{2} \cdot$ M. Villarroel $^{4}$
}

Received: 4 April 2017 / Accepted: 20 September 2017 / Published online: 30 September 2017

(C) Springer Science+Business Media B.V. 2017

\begin{abstract}
Livestock transport exposes animals to a range of potential stressors that may compromise their welfare and final product quality, and those effects typically increase with the distance travelled. In North America, producers often use pot-belly vehicles for long hauls but little is known about their suitability for transporting lambs. We followed two longdistance trips using pot-belly trailers carrying 500 lambs (each) from Northern to Central Mexico in winter, to measure possible effects on animal welfare and meat quality. Sixty lambs per trip were placed at different locations within the pot-belly trailer. Animals were equipped with iButton Thermochron ${ }^{\circledR}$ temperature devices, which registered body temperature throughout pre- and post-slaughter stages. Despite the rather cool winter conditions, lambs placed in the "belly" and "nose" compartments had higher body temperatures at loading, during transport and lairage and after slaughter (carcass temperature). Those lambs also had higher levels of plasma cortisol, glucose and creatine kinase (CK), and a higher neutrophil/lymphocyte ratio. Regarding meat quality, ultimate $\mathrm{pH}(24 \mathrm{~h})$ was higher in all locations,
\end{abstract}

G. C. Miranda-de la Lama

g.miranda@correo.ler.uam.mx

1 Department of Food Science, Metropolitan Autonomous University-Lerma (UAM-L), Lerma, State of México, Mexico

2 Department of Ethology and Wildlife, Faculty of Veterinary Medicine, National Autonomous University of Mexico (UNAM), Mexico City, Mexico

3 Department of Biology and Animal Husbandry, Faculty of Engineering, São Paulo State University (UNESP) Ilha Solteira, São Paulo, Brazil

4 Department of Animal Science, E.T.S.I.A. Polytechnic University of Madrid, Madrid, Spain especially in LT4 location. Overall, the results suggest a link between thermal stress during transport, elevated physiological indicators of stress and poorer meat quality.

Keywords Long-distance transport · Stress hyperthermia . iButton Thermochron ${ }^{\circledR} \cdot$ Hair lambs $\cdot$ Mexico

\section{Introduction}

Safely moving livestock between farms, markets and abattoirs is an essential part of modern animal production (Gilkeson et al. 2016). Nowadays, however, the distances between farms and abattoirs are increasing, due to the economic benefits and greater opportunities of long distance and international trade, improved infrastructure and increased demand for live animals for fattening and slaughtering (Lambooij et al. 2012). Animals have a complex repertoire of adaptive or homeostatic physiological and behavioural mechanisms for dealing with the challenges of constantly changing environments (Fisher et al. 2015). However, during transport, they are exposed to a range of potential stressors which may compromise their welfare, health and performance due to changes in the thermal micro-environment, weather conditions, increased human contact, changes in the social structure (separation or/and mixing), novel/unfamiliar environments, withdrawal of feed and water, dehydration, vibration and acceleration and associated fatigue, loading and unloading stress, noise and environmental pollutants (Miranda-de la Lama et al. 2014). Obviously, long-distance journeys result in inevitable losses in both product quality and quantity. The magnitude of those losses will depend on the intensity and duration of the various stressors that come into play between the farm gate and abattoir and also the susceptibility of the animals to stress (Ferguson et al. 2001). 
Stress-induced hyperthermia is mediated by the autonomic nervous system and is closely associated with the activation of the hypothalamic-pituitary-adrenal axis and the sympatheticadrenal-medullary system. It has been shown to occur prior to and during exposure to some stress-inducing situations (Pedernera-Romano et al. 2011) in numerous species (including sheep), and is characterised by an increase in core body temperature of between 0.5 and $1.5^{\circ} \mathrm{C}$ within 10 to $15 \mathrm{~min}$ of the onset of a stressor (Edgar et al. 2013). Recently, the iButton Thermochron ${ }^{\circledR}$ have been used to record body temperatures via surgical implantations, insertion into the gastrointestinal tract or insertion in the ear canal in wildlife (Roznik and Alford 2012). Recently, iButtons have been validated in sheep to monitor the stress response during road transportation (Pascual-Alonso et al. 2016). Stress can reduce the fitness of an animal, which can be expressed through failure to achieve production performance standards, reduced health, or detrimental effects on the product quality (Rostagno, 2009). Transport stress and physical activity can lead to an increased incidence of dark, firm and dry (DFD) meat due to the depletion of muscle glycogen reserves and the accumulation of lactic acid that alters the normal process of post-mortem acidification of meat, affecting decisive factors of final meat quality such as a darker colour, great variations in tenderness and high water holding capacity and high potential of microbial growth at an early age compared to normal meat (Franco et al. 2015).

Sheep production in Mexico is characterised by long supply chains between breeding farms, feedlots, abattoirs, markets and consumers, with transport distances often above $700 \mathrm{~km}$. Within the livestock sector, sheep breeding has undergone substantial development in recent years compared with other livestock activities, growing by approximately $40 \%$ (Cantón et al. 2009). Farmers of the northern states that border the USA such as Sonora, Chihuahua, Coahuila, Nuevo León and Tamaulipas are increasingly interested in using hair lambs, in production systems integrated with beef cattle, grain and fruit trees (i.e. walnut and apple), or by-products (Esqueda et al. 2013; Chay-Canul et al. 2016). This is mostly motivated by a higher demand for lamb meat in the central states of Mexico and Hidalgo and Mexico City, traditional consumers of barbacoa sheep dish (Rubio et al. 2004). The end result is that sheep farmers and dealers need to transport animals for long distances, leading to a gradual increase in the use of potbelly trailers that can transport large loads (up to 500 lambs) in a single journey. This trailer type is the most commonly used vehicle for livestock transportation in the USA, Canada and Mexico, in large part because of its large load capacity, resulting in decreased transportation cost per animal (Weschenfelder et al. 2012).

Mexico has been slow to update its legal regulations on animal welfare, which includes some guidelines on animal transport, stunning and slaughter throughout the pre- slaughter supply chain (Miranda-de la Lama et al., 2012). Nevertheless, recent scientific evidence in the country indicates growing social concern, in terms of farm animal welfare issues and their ethical, sociological and political implications, as in other parts of the world (Miranda-de la Lama et al., 2017). A considerable number of studies have analysed the effects loading and unloading, novel environments, transport and lairage, space requirements, environmental conditions, driver qualifications and road conditions on the economic losses of sheep production, related to physiological and behavioural stress responses and their impact on meat quality (da Cunha Leme et al. 2012). However, less is known about the effects of location within trailer on animal welfare and meat quality, especially using non-invasive methods as thermophysiological measures. Applied research can help to provide detailed scientific data to help establish uniform national regulations regarding journey times, logistic planning (considering eco-regions along the route) and optimization of logistic resources to minimize the biological cost of long-distance transport. In this study, we aimed to define heat profiles at different locations within pot-belly trailers used for longdistance transport under commercial Mexican conditions of hair lambs and analyze how that affected blood welfare parameters and meat quality.

\section{Material and methods}

The study was carried out in November-December 2014 (winter) to test the effect of location in a transport vehicle on lamb stress during two long-distance journeys. We used 120 male lambs that were loaded onto two commercial pot-belly trailers at the Sheep and Goat Assembly Centre (AC) of the Regional Livestock Union of Coahuila, located in Navas,

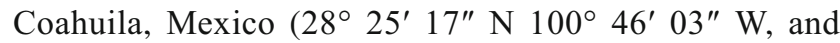
324 masl), and taken via highway to Capulhuac, State of Mexico (19 $12^{\prime} \mathrm{N} 99^{\circ} 28^{\prime} \mathrm{W}$, and 2700 masl), where they were unloaded at a privately owned abattoir. The Navas is the coldest and dry in winter, with means of $13{ }^{\circ} \mathrm{C}$. Capulhuac is characterized by a cold and slightly humid winters, with means of $8{ }^{\circ} \mathrm{C}$. All procedures were conducted within the guidelines of approved local official norms for animal care (NOM-015-ZOO, 2002: Humanitarian care of animals during mobilization; NOM-033-ZOO, 1995: Slaughter of domestic and wild animals).

The lambs used $(n=120)$ were all male and clinically healthy, from a commercial hair breed (crosses of Pelibuey/ Kathadin/Dorper), approximately 200 days old with an average live weight of $46.75( \pm 3.6) \mathrm{kg}$. The lambs were fattened under similar conditions, mainly on naturally improved pasture integrated with walnut and apple, and mineral salt supplements. We carried out two journeys with a difference of 2 weeks between the first and the second, following 60 lambs 
each time. Each journey lasted $20 \mathrm{~h}(17 \mathrm{~h}$ transport $+3 \mathrm{~h}$ of loading and unloading) and the time between the different procedures was maintained the same. Transport, including loading and unloading, was performed under commercial conditions, but monitored by project personnel. All lambs were marked and transported with other non-experimental animals (completing the full capacity of the lorry of approximately 500 lambs).

We analyzed the effect of location of lambs on the trailer on physiological stress indicators, using a factorial model with five treatments and two replicates $(5 \times 2)$. Location within the trailer was defined according to previous experience about where thermal problems arise, and to previous references to problem areas using pot-belly livestock vehicles in pigs (Correa et al. 2014; Conte et al. 2015) and cattle (White et al. 2009; Goldhawk et al. 2015). Five locations were defined (see Fig. 1): LT1, the lowest area of the vehicle close to ground level and wheel axels, usually called the "belly", which is the first compartment to be filled at loading; LT2, the "nose", at the front of the trailer, close to the motor unit; LT3, in the centre, surrounded by other compartments above and below; LT4, at the bottom of the trailer but higher than LT1 and LT3; and LT5, the "dog-house", at the back. At loading, lambs were led in groups of ten, using an external ramp to reach the middle deck, and had to climb an internal ramp $\left(22^{\circ}\right.$ slope) to reach the upper deck, or descend an internal ramp $\left(41^{\circ}\right.$ slope $)$ to reach the belly compartment (Weschenfelder et al. 2012).

The total travelled distance was $1.252 \mathrm{~km}$, mostly on national highways towards the centre of the country. The roads used were $85.3 \%$ Federal Highway 57 (this road links many major highways and has four paved lanes in each direction), $11.7 \%$ Federal Highway 55 (two paved lanes in each direction), and 2.3\% Federal Highway 15 (three paved lanes in each direction) and Mexico State 36 (one paved lane in each direction). The route passed through two important Mexican mountain systems: Sierra Madre Oriental and the TransMexican Volcanic Belt.

The livestock vehicle used was a "pot-belly" trailer (Wilson®, Sioux City, Iowa, USA; Silverstar PSDCL-411, with capacity to $22 \mathrm{t}$ ), provided by the transport company and specialized for sheep, with two axles and four floors, a rigid aluminum chassis and spring-suspension with passive ventilation using symmetric perforations. The door at the back of the trailer was solid with no perforations. The same driver was used on both journeys and the average speed was $80 \mathrm{~km} / \mathrm{h}$, avoiding abrupt accelerations and decelerations. The weather conditions were partially cloudy, with no rain and a fresh breeze (average temperatures of 7.6 and $4.1^{\circ} \mathrm{C}$ ). A bed of wood shavings was placed on the floor of the trailer, and no food or water was provided during transport. Air temperature and relative humidity were recorded every $5 \mathrm{~min}$ throughout transport using data loggers (Testo $®)$ positioned at lamb height. Lambs were slaughtered at a private abattoir specialized for sheep and goats (Capulhuac, State of Mexico), where they remained overnight (approximately $16 \mathrm{~h}$ ) in an indoor lairage area in pens with cemented walls and non-skid floors. Water and feed was freely available, which is normal practice after long-distance transport in sheep private abattoirs of Mexico. After lairage, lambs were stunned and dressed using standard commercial procedures.

The thermo-physiological stress response of lambs ( $n=50$, 25 lambs per journey, 5 per treatment) was measured every 5 min using small (ca. $3 \mathrm{~g}$ ) temperature recording loggers (DS1921G: iButton Thermochron® data loggers, Eclo, Leria Portugal). Before use, each logger was calibrated in a temperature-controlled water bath to $\pm 0.1{ }^{\circ} \mathrm{C}$ at about $5{ }^{\circ} \mathrm{C}$ increments over the range $5-40^{\circ} \mathrm{C}$, against a mercury-in-glass thermometer traceable to a temperature recording loggers (NATA)-calibrated standard. Then, each logger was placed in the inguinal region of the lambs using an adhesive skin patch and externally reinforced with resistant tape (Gorilla Tape ${ }^{\circledR}$, Cincinnati, Ohio, USA), $3 \mathrm{~h}$ before loading and removed $16 \mathrm{~h}$ after unloading. The inguinal temperature data were analyzed in terms of logistic stages (pre-loading, loading, loaded and waiting, road transport, unloading, lairage, handling in the slaughter corridor, slaughter and the first $4 \mathrm{~h}$ post-mortem) and journey segments (Nava-Allende, AllendeRosita, Rosita-Sabinas, Sabinas-Monclova, MonclovaCastaños, Castaños-Saltillo, Saltillo-San Rafael, San RafaelSan Roberto, San Roberto-Matehuala, Matehuala-Huizache, Huizache-San Luis Potosí, San Luis Potosí-San Diego, San

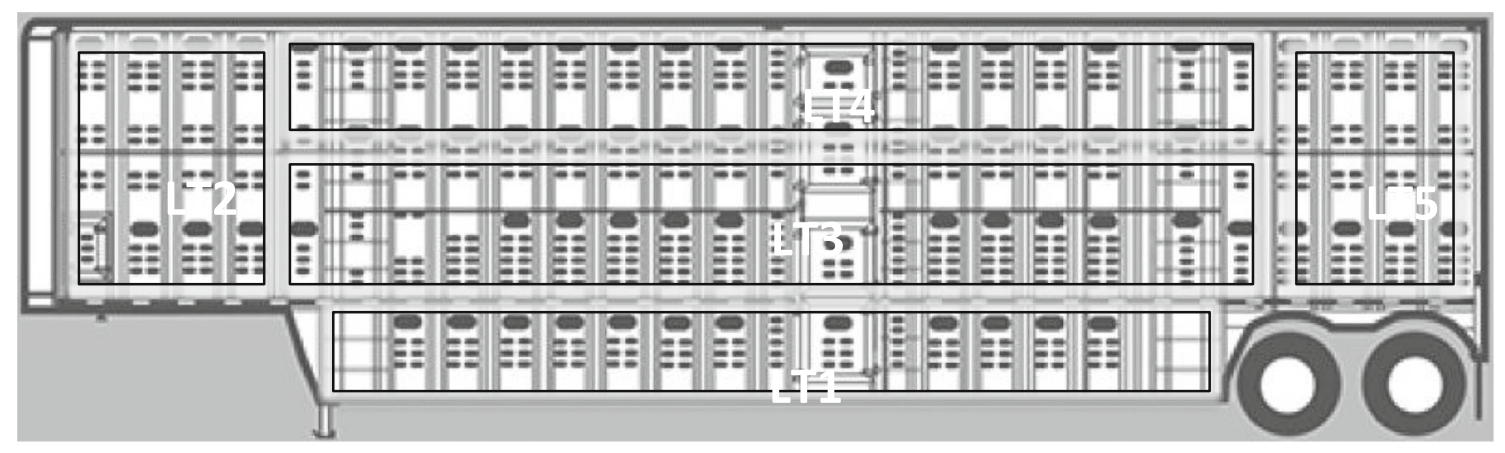

Fig. 1 Experimental trailer design and location of the treatments (LT1, LT2, LT3, LT4 and LT5), within trailer (www.wilsontrailer.com) 
Diego-Querétaro, Querétaro-San Juan del Rio, San Juan del Rio-Palmillas, Palmillas-Atlacomulco, Atlacomulco-Toluca and finally Toluca-Capulhuac).

Blood samples were collected at slaughter $(n=120 \mathrm{lambs})$ to evaluate physiological stress (two 10-ml tubes per animal, with and without anticoagulant, EDTA- $\mathrm{K}_{3}$ ). Samples were kept on ice for a maximum of $2 \mathrm{~h}$ and taken to the laboratory for routine haematological measurements. For the analysis of blood cellular components (haematocrit value, haemoglobin content, erythrocyte and leukocyte counts), EDTA was placed within the blood collection tubes as the anticoagulant, at $2 \mathrm{mg} / \mathrm{ml}$ of blood. Samples in tubes without EDTA were used for blood biochemical components analysis (glucose and cortisol). EDTA plasma and serum were centrifuged at $3000 \times \mathrm{g}$ for $10 \mathrm{~min}$, and aliquots were frozen and kept at $-30^{\circ} \mathrm{C}$ until analysed. The neutrophil:lymphocyte ratio $(\mathrm{N} / \mathrm{L})$ was calculated after treating samples with Wright's stain and counting cells using a microscope. Serum cortisol concentrations ( $\mu \mathrm{g} /$ dl) were measured in duplicate by radioimmunoassay (Clinical Assays GammaCoat Cortisol 125I RIA Kit, DiaSorin, Minnesota, USA), where the inter-assay coefficient of variation was $9.31 \%$. The concentrations of glucose $(\mathrm{mmol} / \mathrm{L})$ and creatine kinase $(\mathrm{CK}, \mathrm{U} / \mathrm{L})$ were determined using a Biosystem kit (Biosystems ${ }^{\circledR}$, Barcelona, Spain) and a spectrophotometer (BTS-330 Biosystems ${ }^{\circledR}$, Barcelona, Spain).

We randomly selected 40 lambs, 8 per 5 locations on the livestock vehicle for meat quality analyses. The $\mathrm{pH}$ of the all samples was recorded at $24 \mathrm{~h}$ post-mortem using a portable $\mathrm{pH}$ meter equipped with a spear-head electrode (meat $\mathrm{pH}$ meter, Hanna HI 99163, HANNA Instruments ${ }^{\circledR}$, USA). Before measurements, the probe was calibrated with standard buffer solutions of $\mathrm{pH} 4$ and 7 that were kept at the same cold room where the carcasses in the experiment were stored. After chilling for $24 \mathrm{~h}$, carcasses were transferred to the Laboratory of Animal Nutrition without disrupting the cold chain. The left M. longissimus was removed, wrapped, frozen at $-20^{\circ} \mathrm{C}$ and stored. The right loin was divided into two sections. The first section was kept on a tray in a refrigerator for $24 \mathrm{~h}$. For water holding capacity (WHC), $2 \mathrm{~g}$ of finely ground meat was placed in a centrifuge tube with $5 \mathrm{~mL}$ of a $0.6 \mathrm{M} \mathrm{NaCl}$ solution, stirred in a vortex for $1 \mathrm{~min}$ and allowed to stand in the refrigerator for $30 \mathrm{~min}$, at $4{ }^{\circ} \mathrm{C}$. The samples were centrifuged for $15 \mathrm{~min}$ at 10,000 rpm in a Beckman J-MI centrifuge (CA, USA). The supernatant was decanted and measured in a test tube. The retained volume of distilled water was reported as the amount of water retained, calculated for $100 \mathrm{~g}$ of meat (Guerrero-Legarreta and Arteaga Martínez, 1990). At 72 h post-mortem and after $1 \mathrm{~h}$ of blooming, instrumental colour was evaluated using a Minolta CM 202-calibrated chromameter with a standard illuminant D65 and a $10^{\circ} \mathrm{ob}$ server with an aperture size of $2.54 \mathrm{~cm}$; following the CIE $\mathrm{L} * \mathrm{a} * \mathrm{~b} *$ system, the colour of the cut surface of the 11 th thoracic vertebra of the $M$. longissimus was measured. Color was expressed according to the Commission International de l'Eclairage (CIE) system and reported as L* (lightness), a* (redness) and $b^{*}$ (yellowness) values. Final values were the average of three measurements.

The second section was vacuum packed, frozen, and stored at $-20^{\circ} \mathrm{C}$ after $72 \mathrm{~h}$. Samples were thawed for $24 \mathrm{~h}$ in a refrigerator $\left(2-4{ }^{\circ} \mathrm{C}\right)$ in their vacuum-sealed plastic bags before testing. To perform the Warner-Bratzler test, samples were cooked in their vacuum-sealed plastic bags in a $75^{\circ} \mathrm{C}$ water bath (GLF-D3006), until the internal temperature of the meat (measured with a penetration thermometer) reached $70{ }^{\circ} \mathrm{C}$, then cooled for $30 \mathrm{~min}$ under flowing cold water. The samples were randomly allocated in two batches. The mean weight of the original samples was $29.1( \pm 2.1) \mathrm{g}$. The texture of the cooked meat was assessed using a TA-XT2 Texture Analyser (Texture Technologies Corp., Scarsdale, NY) equipped with a WarnerBratzler shear attachment (Texture Technologies Corp., Scarsdale, NY). To cut $1-\mathrm{cm}^{2}$ pieces (in the direction of the muscle fibres), a digital calibre MITUTOYO Series 500 (Mitutoyo Corporation, Aurora, IL, USA) was used. For each animal, three measurements were taken.

Data were analyzed using the GLM procedure of SAS (2001). The location of lambs on the trailer was considered as a fixed effect, while residuals were considered random effects. The replicate effect was found to be non-significant and was therefore dropped from the final statistical model. Each individual animal served as an experimental unit for all the parameters assessed. Covariance analysis, with cold carcass weight as a covariate, was used to correct for the meat variables studied. In all analyses, when least squares means were different at $P \leq 0.05$, they were separated by the PDIFF option of SAS.

\section{Results}

The average temperature was $16.1( \pm 2.7){ }^{\circ} \mathrm{C}$ and 15.9 $( \pm 3.3){ }^{\circ} \mathrm{C}$ with a relative humidity of $61.3( \pm 5.3)$ and 60.0 ( \pm 4.3$) \%$, for journeys 1 and 2, respectively. During lairage, the average temperature was $22.3( \pm 1.80)$ and 25.5 $( \pm 3.33){ }^{\circ} \mathrm{C}$ with a relative humidity of $67.7( \pm 1.4)$ and 66.0 $( \pm 1.9) \%$, for journeys 1 and 2 , respectively.

In general, we found a marked response of hyperthermia in locations LT1 and LT2 (Table 1). However, in the analysis of logistic steps and journey period by eco-regions, there were some effects in other locations on the trailer. In logistics steps, in the pre-loading stage, we did not find differences among locations, but at loading, the body temperature of lambs in LT1, LT2 and LT5 was higher compared to that in other groups. Once embarked, during the journeys and at unloading, lambs in LT1 and LT2 had hyperthermia compared with those in LT3, LT4 and LT5. In lairage, the animals that had been in LT1, LT2 and LT3 had higher temperature values. At handling 
Table 1 Least square means $( \pm \mathrm{SE})$ expressed in grade centigrade $\left({ }^{\circ} \mathrm{C}\right)$ and significance levels for the effect of the location on trailer on thermo-physiology profile according logistic step assessed at long distance transport of hair lambs in Mexico

\begin{tabular}{llllll}
\hline Logistic step & \multicolumn{5}{l}{ Location on trailer } \\
\cline { 2 - 6 } & LT1 & LT2 & LT3 & LT4 & LT5 \\
\hline Pre-loading* & $35.5( \pm 0.07)$ & $35.5( \pm 0.09)$ & $35.0( \pm 0.04)$ & $35.0( \pm 0.08)$ & $35.0( \pm 0.03)$ \\
Loading & $37.0( \pm 0.07)^{\mathrm{a}}$ & $37.0( \pm 0.05)^{\mathrm{a}}$ & $36.5(0.07)^{\mathrm{b}}$ & $36.5( \pm 0.09)^{\mathrm{b}}$ & $37.0( \pm 0.08)^{\mathrm{a}}$ \\
Embarked & $38.0( \pm 0.08)^{\mathrm{a}}$ & $38.0( \pm 0.05)^{\mathrm{a}}$ & $37.0( \pm 0.08)^{\mathrm{b}}$ & $37.0( \pm 0.09)^{\mathrm{b}}$ & $37.0( \pm 0.02)^{\mathrm{b}}$ \\
Journey & $38.5( \pm 0.06)^{\mathrm{a}}$ & $38.0( \pm 0.07)^{\mathrm{a}}$ & $36.5( \pm 0.07)^{\mathrm{b}}$ & $35.5( \pm 0.07)^{\mathrm{b}}$ & $36.0( \pm 0.07)^{\mathrm{b}}$ \\
Unloading & $38.0( \pm 0.03)^{\mathrm{a}}$ & $38.5( \pm 0.08)^{\mathrm{a}}$ & $36.5( \pm 0.03)^{\mathrm{b}}$ & $36.25( \pm 0.01)^{\mathrm{b}}$ & $36.5( \pm 0.04)^{\mathrm{b}}$ \\
Lairage & $38.5( \pm 0.07)^{\mathrm{a}}$ & $38.5( \pm 0.07)^{\mathrm{a}}$ & $37.5( \pm 0.01)^{\mathrm{b}}$ & $37.5( \pm 0.07)^{\mathrm{b}}$ & $38.0( \pm 0.06)^{\mathrm{a}}$ \\
Handling at the & $38.5( \pm 0.04)^{\mathrm{a}}$ & $38.0( \pm 0.07)^{\mathrm{b}}$ & $37.5( \pm 0.06)^{\mathrm{b}}$ & $37.5( \pm 0.05)^{\mathrm{b}}$ & $37.5( \pm 0.08)^{\mathrm{b}}$ \\
$\quad$ slaughter corridor & & & & & \\
Slaughter & $38.5( \pm 0.04)^{\mathrm{a}}$ & $38.0( \pm 0.06)^{\mathrm{a}}$ & $36.7( \pm 0.06)^{\mathrm{b}}$ & $37.5( \pm 0.04)^{\mathrm{b}}$ & $37.5( \pm 0.04)^{\mathrm{b}}$ \\
Carcass** & $25.3( \pm 0.08)^{\mathrm{a}}$ & $24.5( \pm 0.08)^{\mathrm{a}}$ & $21.6( \pm 0.07)^{\mathrm{b}}$ & $22.7( \pm 0.07)^{\mathrm{b}}$ & $22.5( \pm 0.06)^{\mathrm{b}}$ \\
\hline
\end{tabular}

a, b, c: different letters at the same row means significant difference within treatments $(P \leq 0.05)$; * An hour before starting loading operations; ** First $4 \mathrm{~h}$ in the slaughter corridor and at slaughter, LT1 and LT2 animals had higher temperatures. Finally, the average temperature of carcasses during the first $4 \mathrm{~h}$ post-mortem indicates that LT1 and LT2 lambs had a higher temperature than LT3, LT4 and LT5 lambs.

In the case of the body temperature, along 18 segments of the route, temperatures were higher in lambs at LT1 and LT2 $(P \leq 0.05$; Table 2). The lowest mean value recorded was a body temperature of $34.4^{\circ} \mathrm{C}$ in LT4 from Sabinas-Monclova, and the highest was $38.4^{\circ} \mathrm{C}$ for LT2 on the last stage (TolucaCapulhuac). Seven segments had higher average temperatures in the five compartments and could be considered critical routes: San Rafael-San Roberto $\left(36.6^{\circ} \mathrm{C}\right.$, crossing the Sierra Madre Oriental), Matehuala-Huizache $\left(36.52^{\circ} \mathrm{C}\right)$, HuizacheSan Luis Potosi $\left(36.4{ }^{\circ} \mathrm{C}\right)$, San Luis Potosi-San Diego $\left(36.4{ }^{\circ} \mathrm{C}\right)$, Palmillas-Atlacomulco $\left(36.5{ }^{\circ} \mathrm{C}\right)$, TolucaAtlacomulco $\left(36.9^{\circ} \mathrm{C}\right)$ and Toluca-Capulhuac $\left(37.08^{\circ} \mathrm{C}\right)$.

The least square means $( \pm \mathrm{SE})$ of blood indicators are presented in Table 3. Location within the trailer had a significant effect on all variables, except for haematocrit levels. Cortisol, glucose, CK and the N/L ratio were significantly higher $(P \leq 0.05)$ in LT1 and LT2 lambs. The average cold carcass weight was $23.5( \pm 3.28) \mathrm{kg}$. The least square means $( \pm \mathrm{SE})$ of the meat traits are presented in Table 3. The LT4 group had higher $\mathrm{pH}$ values $(P \leq 0.05)$ and significantly lower $\mathrm{L}^{*}$ values $(P \leq 0.05)$. Texture (gf) by Warner-Bratzler was higher in lambs from LT4 $(P \leq 0.05)$. There were no significant differences among $\mathrm{WHC}$ values and $\mathrm{a}^{*}$ and $\mathrm{b}^{*}$ colour traits among the different locations within the trailer.

\section{Discussion}

In general, our results indicate that lambs transported over long distances using pot-belly trailers were more stressed in locations LT1 and LT2 (defined above), with higher levels of cortisol, glucose, CK, N/L ratio and thermo-physiological profiles related to stress, as well as differences in some meat quality traits. The use of pot-belly trailers has been criticized because of the difficult handling at loading and unloading due to steep internal ramps and poor internal climate conditions, resulting in greater animal losses and poor meat quality when compared with other trailer models, both for pigs (Conte et al. 2015) and cattle (White et al. 2009; Goldhawk et al. 2015). However, less is known about the effects of pot-belly trailers on the thermo-physiology, blood constituents and meat quality of lambs.

One of the purposes of the present study was to validate whether temperature-registered buttons could be used as a non-invasive method for measuring body temperature of lambs during journey conditions. Based on earlier reports, sheep body temperatures measured at the perineum, the axillae and the inner thigh are highly correlated with rectal temperature (Mendes et al. 2013); however, those areas can also be considerably affected by the environmental temperature. We used the inguinal area in the present study as it is easier to stick the logger (little hair) and is more protected from the outside temperature. In lambs, the average inguinal temperature is $36^{\circ} \mathrm{C}$ and the rectal temperature is $39^{\circ} \mathrm{C}$, in the thermoneutral zone (Marai et al. 2007). There is evidence that the inguinal temperature and the rectal are highly correlated as the animals get older, since the mammary gland and scrotum are completely developed, preserving the body temperature (Katsoulos et al. 2016). Under our conditions, the journeys were carried out in the colder season and the lambs were all males less than 7 months old, with incompletely developed testicles. That would explain the $3{ }^{\circ} \mathrm{C}$ variation in our study with respect to the rectal temperature provided by other authors (Titto et al. 2016).

The homogeneity of the groups in terms of hyperthermia from stress before loading was evident since there were no differences between the initial temperatures in the five tested 


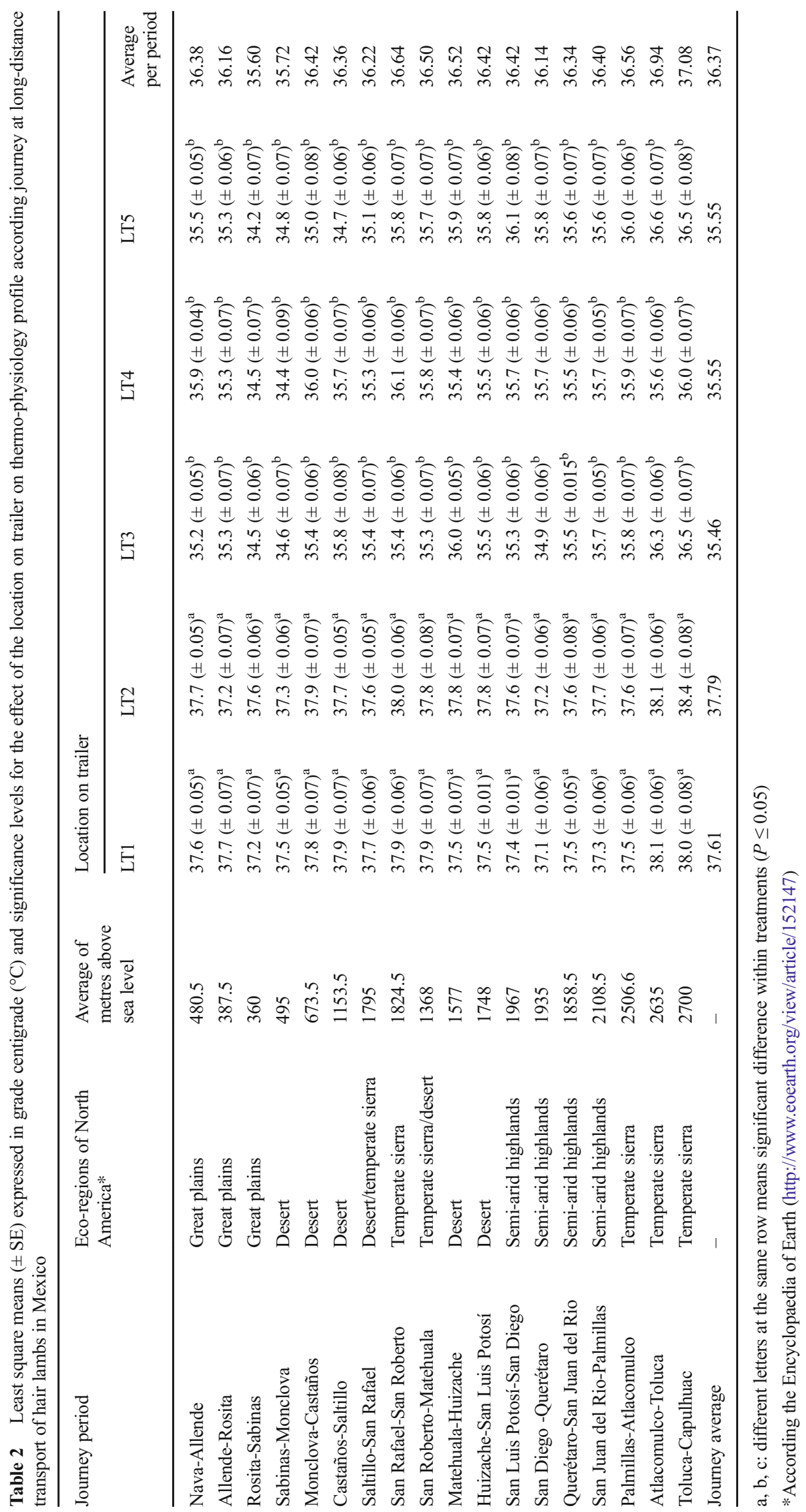


Table 3 Least square means ( \pm SE) and significance levels for the effect of the location on trailer on blood constituents and meat quality traits at longdistance transport of hair lambs in Mexico

\begin{tabular}{|c|c|c|c|c|c|}
\hline \multirow[t]{2}{*}{ Variables } & \multicolumn{5}{|c|}{ Location on trailer } \\
\hline & LT1 & LT2 & LT3 & LT4 & LT5 \\
\hline \multicolumn{6}{|l|}{ Blood constituents } \\
\hline Cortisol (ng/ml) & $19.13( \pm 1.22)^{\mathrm{a}}$ & $18.18( \pm 1.22)^{\mathrm{a}}$ & $10.18( \pm 1.22)^{\mathrm{b}}$ & $12.35( \pm 1.22)^{\mathrm{b}}$ & $10.44( \pm 1.22)^{\mathrm{b}}$ \\
\hline Glucose $(\mathrm{mg} / \mathrm{ml})$ & $55.42( \pm 1.68)^{\mathrm{a}}$ & $57.16( \pm 1.68)^{\mathrm{a}}$ & $67.78( \pm 1.68)^{\mathrm{b}}$ & $59.16( \pm 1.68)^{\mathrm{b}}$ & $63.16( \pm 1.68)^{\mathrm{b}}$ \\
\hline CK (U/I) & $889( \pm 90)^{\mathrm{a}}$ & $901( \pm 90)^{\mathrm{a}}$ & $767( \pm 90)^{\mathrm{b}}$ & $741( \pm 90)^{\mathrm{b}}$ & $703( \pm 90)^{\mathrm{b}}$ \\
\hline Haematocrit (\%) & $47.27( \pm 0.33)$ & $46.45( \pm 0.33)$ & $47.17( \pm 0.33)$ & $47.33( \pm 0.33)$ & $47.38( \pm 0.33)$ \\
\hline Ratio N/L & $1.04( \pm 0.07)^{\mathrm{a}}$ & $0.94( \pm 0.07)^{\mathrm{a}}$ & $0.66( \pm 0.07)^{\mathrm{b}}$ & $0.79( \pm 0.07)^{\mathrm{b}}$ & $0.64( \pm 0.07)^{\mathrm{b}}$ \\
\hline \multicolumn{6}{|l|}{ Meat quality } \\
\hline $\mathrm{pHu}_{24}$ & $5.8( \pm 0.08)^{\mathrm{a}}$ & $5.8( \pm 0.08)^{\mathrm{a}}$ & $5.79( \pm 0.08)^{\mathrm{a}}$ & $6.04( \pm 0.08)^{\mathrm{b}}$ & $5.76( \pm 0.08)^{\mathrm{a}}$ \\
\hline WHC (ml/g) & $1.91( \pm 0.20)$ & $1.88( \pm 0.20)$ & $1.96( \pm 0.20)$ & $2.58( \pm 0.20)$ & $2.25( \pm 0.20)$ \\
\hline Texture (gf) & $19.38( \pm 0.97)^{\mathrm{a}}$ & $17.68( \pm 0.97)^{\mathrm{a}}$ & $18.28( \pm 0.97)^{\mathrm{a}}$ & $21.72( \pm 0.97)^{\mathrm{b}}$ & $17.96( \pm 0.97)^{\mathrm{a}}$ \\
\hline \multicolumn{6}{|l|}{ Colour } \\
\hline $\mathrm{L}^{*}$ & $36.08( \pm 0.58)^{\mathrm{a}}$ & $37.00( \pm 0.58)^{\mathrm{a}}$ & $37.62( \pm 0.58)^{\mathrm{a}}$ & $35.83( \pm 0.58)^{\mathrm{b}}$ & $36.75( \pm 0.58)^{\mathrm{a}}$ \\
\hline$a^{*}$ & $9.46( \pm 1.0)$ & $9.25( \pm 1.0)$ & $9.59( \pm 1.0)$ & $9.75( \pm 1.0)$ & $9.41( \pm 1.0)$ \\
\hline $\mathrm{b}^{*}$ & $10.43( \pm 0.19)$ & $10.55( \pm 0.18)$ & $10.41( \pm 0.18)$ & $10.36( \pm 0.18)$ & $10.52( \pm 0.18)$ \\
\hline
\end{tabular}

a, b, c: different letters at the same row means significant difference within treatments $(P \leq 0.05)$

$C K$ creatine kinase, $W H C$ water holding capacity, $L^{*}$ luminosity, $a^{*}$ red index, $b *$ yellow index

groups, which can be taken as basal. Regarding the loading of lambs, LT1, LT2 and LT5 had higher temperatures, compared with LT3 and LT4. That is probable since the handlers did not always load in the same manner, and there were delays before the vehicle moved, which is common in livestock transport (Romero et al. 2013). Another possible explanation is that the LT1 and LT2 lambs required more handling to enter into the compartments using the internal ramps of the trailer, while the animals from group LT5 were the last to load and had been handled constantly before and during the loading, spending more time in the pre-loading pens. In addition, the use of the electric prod is quite common while handling sheep in the North of Mexico, and it was used frequently by the handlers during the current study.

In the case of loading, the journey itself and unloading, the lambs LT1 and LT2 had a marked hyperthermia compared to other groups. That stressing effect can be due to the design of the truck since those animals are the first to load and the last to unload (Weschenfelder et al. 2012). According to Krawczel et al. (2007), one of the most stressful situations for lambs is waiting on a stopped truck. In addition to that, both problem locations have similar attributes that can exacerbate the stress response. In the case of the LT1 group, it is close to the level of the axels of the truck, so it is darker, hotter and more humid and undergoes more vibration, in addition to receiving more urine and feces from higher levels. This compartment has been reported to be problematic in many studies in other species (Correa et al. 2014; Conte et al. 2015; White et al. 2009; Goldhawk et al. 2015). Location LT2 is exposed to more noise since it is beside the elevated exhaust system, especially when the motor brake is on going down mountains. Livestock hauliers also complain about noise from the exhaust, disturbing sleep in the nearby cabin when they are taking turns driving (Darwent et al. 2012). Noise insulation in the compartments in the nose or the use of exhaust silencers could attenuate this stressful effect.

There are three fundamental reasons why the lambs, after being unloaded at the abattoir, have a long lairage period. First, it provides time to recover from the journey (Liste et al. 2011). Secondly, it allows more time to plan the slaughter by groups according to commercial requirements, and thirdly, it gives time to inspect the animals. In our study, LT1, LT2 and LT5 lambs had higher temperatures than LT3 and LT4 lambs, probably as a result of the accumulative effect of the different stages of loading, embankment, the journey itself and unloading. Also, LT5 lambs are the first to unload, which implies emotional reactivity since they are moved immediately to a novel pen (Dalla Costa et al. 2007). On the other hand, LT1 and LT2 lambs were the last to unload, which could explain the higher temperatures (since unloading lasts longer), and they have hyperthermia during transport, which lasts during lairage and even after slaughter since the carcass temperature was significantly higher during the first 4 hours post-mortem. Stress hyperthermia has been reported to decrease the rate of carcass cooling since the starting temperature is higher. That affects how the temperature declines post-mortem and meat quality (Ferguson et al. 2001; Jacob et al. 2014).

Inspired by precision agriculture, precision livestock transport is a developing field, with an increased used of sensor 
technology (Pascual-Alonso et al. 2016). Our study has shown that iButton Thermochron ${ }^{\circledR}$ are useful to measure body temperature in lambs under commercial conditions. The temperatures can then be correlated with specific events such as segments of the journey that are problematic in terms of welfare. Despite the marked hyperthermia for all animals during the journey we analyzed, the body temperature of LT1 and LT2 lambs was significantly higher, indicating a high level of stress. Pot-belly trailers were designed to optimize space and stocking rates but there is a cost in terms of welfare and comfort for the animals during long distances. New designs based on the results of further scientific studies should help alleviate those problems.

The hypothalamic-pituitary-adrenal axis is strongly stimulated throughout transport, lairage and slaughter and is linked to the duration of those logistics steps (Fazio and Ferlazzo 2003). The LT1 and LT2 lambs had higher levels of cortisol, glucose, CK and N/L ratio, suggesting that they underwent more stress than LT3, LT4 and LT5 lambs, both during transport and $16 \mathrm{~h}$ of lairage. A possible explanation could be related to the probable strong negative correlation between humidity, temperature or ammonia levels (from excreta-not measured in our study), and the lack of ventilation capacity of nose and belly compartments provoking a stagnant airflow and consequently detrimental effects on animal welfare (Zhang et al. 2017). More recent studies relating specifically to small livestock trailers illustrate the difference in ventilation rates between nose, upper deck and lower deck; air movement on the lower deck is generally much less than that on the nose and upper deck (Gilkeson et al. 2016). In our study, blood samples were taken during bleeding only and thus, changes in cortisol release during the logistics steps could not be determined. Even so, our results confirm the negative effects of the nose and belly compartments at the physiological level and provide useful information regarding the biological cost of adaptation to long-distance transport in these locations within the trailer.

Ante-mortem stress entails important modifications in the post-mortem biochemistry of muscle and meat quality. The major effect is exerted through its influence on mobilization of muscle glycogen stores. If these are reduced or depleted at slaughter, the extent of post-mortem acidification is consequently reduced (Beltrán et al. 1997). The ultimate $\mathrm{pH}$ for classifying meat as DFD is traditionally thought to be above pH 6.0, yet some argue it could be as low as 5.8 (Page et al. 2001; England et al. 2016). The elevated pH values found in this study indicate that $16 \mathrm{~h}$ of transport produces stress, elevating plasma indicators and presumably increasing the amount of energy needed to maintain equilibrium. The $\mathrm{pH}$ values ranged between 5.7 and 6 , in addition to the alterations in some variables of texture and color $\left(L^{*}\right)$, which would indicate that it is meat close to a DFD condition. Those results agree with Carter and Gallo (2008), who found no significant differences in meat $\mathrm{pH}$ between lambs that underwent short (12 h) or long transport (46 h). However, other authors report that transportation on a rough road for $4 \mathrm{~h}$ significantly increases ultimate $\mathrm{pH}$, compared to that on a smooth road (Miranda-de la Lama et al. 2011), and Apple et al. (1995) found that muscle from restraint-stressed sheep had significantly higher ultimate $\mathrm{pH}$ values than that from unstressed animals. It is important to underline that the animals that undergo stress during transport do not necessarily have to show signs of DFD meat, and that even a moderate stress can influence the ultimate $\mathrm{pH}$ (Terlouw, 2015). The lack of effect on meat quality does not indicate a lack of suffering or pain. The relation between the initial content of glycogen in the muscle and the ultimate $\mathrm{pH}$ is only linear at low levels of glycogen (María, 2008). It is quite probable that the impact of longdistance transport on meat was attenuated by the $16 \mathrm{~h}$ of lairage, access to water and food and the good initial conditions of the lambs at loading.

\section{Conclusions}

Our results indicate that locations LT1 and LT2 cause a marked effect during long-distance transport of haired lambs. The iButtons were sensitive and precise in the commercial journeys and allowed to differentiate among animals in the same journey in addition to logistical conditions and operational difficulties. The pot-belly trailers are part of the agrofood reality produced by the integration of Mexico with the USA and Canada in the NAFTA free-trade agreement in the past 30 years. An understanding of effects of long-distance transport using precision livestock techniques, including those non-invasive monitoring using sensors, will enable livestock hauliers to improve animal welfare during long-distance transport of commercial hair lambs in Mexico by efficiently monitoring the micro-climatic conditions and taking appropriate actions to control excesses. But the data suggests that Mexican companies need to develop their own trailers that have the same operational efficiency and respect animal welfare as components of their design. It would also be good to develop regulations and guidelines for transport in Mexico in terms of transport time and transporting conditions, with a long-term view to obtain improvements in the conditions of the thousands of lambs that travel, avoiding suffering and preventing losses for the industry.

Acknowledgments This study was funded by the Mexican Government (SEP-Promep), project number 103.5/13/8925 UAM-PTC417, "Effects of road transport of lambs in Mexico". Thanks to the National Council on Science and Technology (CONACyT) for the MSc scholarship for M. Rodríguez-Palomares. The authors would like to thank Jesus Martinez and his family for practical and logistic support during on field activities and Gustavo Palacios for the help provided on the field activities. 


\section{Compliance with ethical standards}

Ethical approval All applicable international, national and/or institutional guidelines for care and use of animals were followed.

Conflict of interests The authors declare that they have no conflict of interest.

\section{References}

Apple, J.K., Dikeman, M.E., Minton, J.E., McMurphy, R.M., Fedde, M.R., Leith, D.E., 1995. Effects of restraint and isolation stress and epidural blockade on endocrine and blood metabolite status, muscle glycogen metabolism and incidence of dark-cutting longissimus muscle of sheep. J. Anim. Sci. 73, 2295-2307.

Beltrán, J.A., Jaime, I., Santolaria, P., Sañudo, C., Albertí, P., Roncalés, P., 1997. Effect of stress-induced high post-mortem $\mathrm{pH}$ on protease activity and tenderness of beef. Meat Sci. 45, 201-207.

Cantón, G.C.J., Bores, Q.R., Baeza, R.J., Quintal, F.J., Santos, R.R., Sandoval, C.C., 2009. Energy retention of F1 Pelibuey lambs crossed with breeds for meat production. J. Anim. Vet. Adv. 8, 2655-2661.

Carter, L.M., Gallo, C.B., 2008. Efectos del transporte prolongado por vía terrestre y cruce marítimo en transbordador sobre pérdidas de peso vivo y características de la canal en corderos. Arch. Med. Vet. 40, 259-266.

Chay-Canul, A.J., Magaña-Monforte, J.G., Chizzotti, M.L., PiñeiroVázquez, A.T., Canul-Solís, J.R., Ayala-Burgos, A.J., Ku-Vera, J.C., Tedeschi, L.O., 2016. Requerimientos energéticos de ovinos de pelo en las regiones tropicales de Latinoamérica. Revisión. Rev. Mex. Cien. Pecu. 7, 105-125.

Conte, S., Faucitano, L., Bergeron, R., Torrey, S., Gonyou, H. W., Crowe, T., Tamminaga, E.T., Widowski, T.M., 2015. Effects of season, truck type, and location within truck on gastrointestinal tract temperature of market-weight pigs during transport. J. Anim. Sci. 93, 58405848 .

Correa, J.A., Gonyou, H., Torrey, S., Widowski, T., Bergeron, R., Crowe, T., Laforest, J.P., Faucitano, L., 2014. Welfare of pigs being transported over long distances using a pot-belly trailer during winter and summer. Animals. 4, 200-213.

da Cunha Leme, T. M., Titto, E. A. L., Titto, C. G., Amadeu, C. C. B., Neto, P. F., Vilela, R. A., Pereira, A. M. F. 2012. Influence of transportation methods and pre-slaughter rest periods on cortisol level in lambs. Small Rumin. Res. 107, 8-11.

Dalla Costa, O.A., Faucitano, L., Coldebella, A., Ludke, J.V., Peloso, J.V., Dalla Roza, D., da Costa, M.P., 2007. Effects of the season of the year, truck type and location on truck on skin bruises and meat quality in pigs. Livest. Sci. 107, 29-36.

Darwent, D., Roach, G., Dawson, D., 2012. How well do truck drivers sleep in cabin sleeper berths?. Appl. Ergon. 43, 442-446.

Edgar, J.L., Nicol, C.J., Pugh, C.A., Paul, E.S. 2013. Surface temperature changes in response to handling in domestic chickens. Physiol. Behav. 119, 195-200.

England, E.M., Matarneh, S.K., Oliver, E.M., Apaoblaza, A., Scheffler, T.L., Shi, H., Gerrard, D.E. 2016. Excess glycogen does not resolve high ultimate $\mathrm{pH}$ of oxidative muscle. Meat Sci. 114, 95-102.

Esqueda, M.H., Castillo, F.R., Rollo, M.M., 2013. Producion ovina en nogaleras. INIFAP. Centro de Investigación Regional Norte Centro. Sitio Exp. La Campana. Folleto Técnico No. 43, 24 pp.

Fazio, E., Ferlazzo, A., 2003. Evaluation of stress during transport. Vet. Res. Commun. 27, 519-524.
Ferguson, D.M., Bruce, H.L., Thompson, J.M., Egan, A.F., Perry, D., Shorthose, W.R., 2001. Factors affecting beef palatability-farm gate to chilled carcass. Anim. Prod. Sci. 41, 879-891.

Fisher, M.W., Muir, P.D., Gregory, N.G., Thomson, B.C., Smith, N.B., Johnstone, P.D., Bicknell, N., 2015. The effects of depriving feed to facilitate transport and slaughter in sheep-a case study of cull ewes held off pasture for different periods. New Zeal. Vet. J. 63, 260-264.

Franco, D., Mato, A., Salgado, F.J., López-Pedrouso, M., Carrera, M., Bravo, S., Parrado, M., Gallardo, J.M., Zapata, C., 2015. Tackling proteome changes in the longissimus thoracis bovine muscle in response to pre-slaughter stress. J. Proteom. 122,73-85.

Gilkeson, C.A., Thompson, H.M., Wilson, M.C.T., Gaskell, P.H., 2016. Quantifying passive ventilation within small livestock trailers using Computational Fluid Dynamics. Comput. Electron. Agr. 124, 84 99.

Goldhawk, C., Janzen, E., González, L. A., Crowe, T., Kastelic, J., Kehler, C., Siemens, M., Ominski, K., Pajor, E., SchwartzkopfGenswein, K.S., 2015. Trailer temperature and humidity during winter transport of cattle in Canada and evaluation of indicators used to assess the welfare of cull beef cows before and after transport. J. Anim. Sci. 93, 3639-3653.

Guerrero-Legarreta, I., Arteaga Martínez, M.R., (1990). Tecnología de carnes: Elaboración y preservación de productos cárnicos, Trillas, Mexico, D.F

Jacob, R.H., Surridge, V.S.M., Beatty, D.T., Gardner, G.E., Warner, R.D., 2014. Grain feeding increases core body temperature of beef cattle. Anim. Prod. Sci. 54, 444- 449.

Katsoulos, P. D., Athanasiou, L. V., Karatzia, M. A., Valasi, I., Boscos, C., Karatzias, H., 2016. Comparison of a non-contact infrared thermometer with a rectal digital thermometer for use in ewes. Small Rumin. Res. 143, 84-88.

Krawczel, P.D., Friend, T.H., Caldwell, D.J., Archer, G., Ameiss, K., 2007. Effects of continuous versus intermittent transport on plasma constituents and antibody response of lambs. J. Anim. Sci. 85, 468.

Lambooij, E., van der Werf, J.T.N., Reimert, H.G.M., Hindle, V.A., 2012. Compartment height in cattle transport vehicles. Livest. Sci. 148, 87-94.

Liste, G., Miranda-De La Lama, G.C., Campo, M.M., Villarroel, M., Muela, E., María, G.A., 2011. Effect of lairage on lamb welfare and meat quality. Anim. Prod. Sci. 51, 952-958.

Marai, I.F.M., El-Darawany, A.A., Fadiel, A., Abdel-Hafez, M.A.M., 2007. Physiological traits as affected by heat stress in sheep-a review. Small Rumin. Res. 71, 1-12.

María, G.A., 2008. Meat quality. In M. C. Appleby (Ed.), Long distance transport and welfare of farms animals (pp. 77-112). Wallingford, U.K.: CABI Publishing.

Mendes, L.C.N., Matsukuma, B.H., Oliveira, G., Peres, L.C.T., Gerardi, B., Feitosa, F.L.F., Perri, S.H.V., Peiró, J.R., 2013. Effect of shearing on the skin temperature and other clinical parameters in sheep. Pesqui. Vet. Bras. 33, 817-825.

Miranda-de la Lama, G.C., Estévez-Moreno, L.X., Sepúlveda, W.S., Estrada-Chavero, M.C., Rayas-Amor, A.A., Villarroel, M., María, G.A. 2017. Mexican consumers' perceptions and attitudes towards farm animal welfare and willingness to pay for welfare friendly meat products. Meat Sci. 125, 106-113.

Miranda-de la Lama, G.C., Leyva, I.G., Barreras-Serrano, A., PérezLinares, C., Sánchez-López, E., María, G.A., Figueroa-Saavedra, F. 2012. Assessment of cattle welfare at a commercial slaughter plant in the northwest of Mexico. Trop. Anim. Health Prod. 44, 497-504.

Miranda-de la Lama, G.C., Monge, P., Villarroel, M., Olleta, J. L., GarcíaBelenguer, S., \& María, G.A. 2011. Effects of road type during transport on lamb welfare and meat quality in dry hot climates. Trop. Anim. Health Prod. 43, 915-922. 
Miranda-de la Lama, G.C., Villarroel, M., María, G.A. 2014. Livestock transport from the perspective of the pre-slaughter logistic chain: a review. Meat Sci. 98, 9-20.

Pascual-Alonso, M., Miranda-de la Lama, G. C., Aguayo-Ulloa, L., Villarroel, M., Mitchell, M., María, G.A. 2016. Thermophysiological, haematological, biochemical and behavioural stress responses of sheep transported on road. J. Anim. Physiol. Anim. Nutr. 101, 541-551.

Page, J.K., Wulf, D.M., Schwotzer, T.R. 2001. A survey of beef muscle color and pH. J. Anim. Sci. 79, 678.

Pedernera-Romano, C., Ruiz de la Torre, J. L., Badiella, L., Manteca, X., 2011. Associations between open-field behaviour and stressinduced hyperthermia in two breeds of sheep. Anim. Welf. 20, 339-346.

Romero, M.H., Uribe-Velasquez, L.F., Sánchez, J.A., Miranda-de La Lama, G.C., 2013. Risk factors influencing bruising and high muscle $\mathrm{pH}$ in Colombian cattle carcasses due to transport and preslaughter operations. Meat Sci. 95, 256-263.

Rostagno, M.H., 2009. Can Stress in Farm Animals Increase Food Safety Risk? Foodborne Pathog. Dis. 6,767-776.

Roznik, E.A., Alford, R.A., 2012. Does waterproofing Thermochron iButton dataloggers influence temperature readings? J. Thermal Biol. 37, 260-264.
Rubio, M.S., Torres, N., Gutiérrez, J., Méndez, R.D., 2004. Composition and sensory evaluation of lambs carcasses used for the traditional Mexican lamb dish, "barbacoa". Meat Sci. 67, 359-364.

Terlouw, C., 2015. Stress reactivity, stress at slaughter and meat quality. In: Meat Quality: Genetic and Environmental Factors, pp 199-217. PCRC Press, Philadelphia, Pa, USA.

Titto, C.G., Veríssimo, C.J., Pereira, A.M.F., de Mira Geraldo, A., Katiki, L.M., \& Titto, E. A.L., 2016. Thermoregulatory response in hair sheep and shorn wool sheep. Small Rumin. Res. 144, 341-345.

Weschenfelder, A.V., Torrey, S., Devillers, N., Crowe, T., Bassols, A., Saco, Y., Piñeiro, M., Saucier, L., Faucitano, L., 2012. Effects of trailer design on animal welfare parameters and carcass and meat quality of three Pietrain crosses being transported over a long distance. J. Anim. Sci. 90, 3220-3231.

White, B. J., Blasi, D., Vogel, L. C., Epp, M., 2009. Associations of beef calf wellness and body weight gain with internal location in a truck during transportation. J. Anim. Sci. 87, 4143-4150.

Zhang, Y., Lisle, A.T., Phillips, C.J. 2017. Development of an effective sampling strategy for ammonia, temperature and relative humidity measurement during sheep transport by ship. Biosyst. Eng. 155, 12-23. 